\title{
TABLE OF CONTENTS-(Continued).
}

REVIEWS OP BOOKS- PLaE

Revue des Etudes Islamiques. Tome III (H. A. R. Gibb) . . . . 1013

History of Paleatine and Syria to the Macedonian Conquest. By A. T. Olmstead (H. A. R. Gibb) ${ }^{\circ}{ }^{\circ}$ Robinson, $\dot{J}^{\circ}$ Hunkin and

Palestine in General History. By T. H. Robinson, J. W. Hunkin and
F. C. Burkitt (H. A. R. Gibb)

Pstra et is Nabatene By A. Kammerer (H. A, R. Gibb) • • 1015

History of Paleatine. By A. S. Rappoport (H. A. R. Gibb) : : 1015

The Legacy of Lolam. Edited by the late Sir Thomas Arnold and

A. Guillaume (A. S. Tritton)
Summa Philosophise. Al-Shahrastani. Edited by A.' Guillaume (A. S. Tritton) fife and Times of Sultan Mabmūd of Ghazna. By Muhammad Näzim (V. Minorsky) . . . . . . . . . 1021

A Persian Journey. By Fred Richards (E. Denison Ross) : . : . 1026

Tärikh-i Mubārak Shāhi. Bibliotheca Indica (Wolseley Haig) : : 1027

Grammaire élémentaire du Sanskrit classique. By Henri Courbin

The Thirteen Principal Upanishads. Translated by R. B. Hume. Secord edition (J. Charpentier) ${ }^{*} \cdot \bullet^{*} \cdot{ }^{*} \cdot{ }^{*} \cdot$

Pramsna Samuccaya. Edited by H. R. Ramaswamy Iyengar

(J. Charpentier)
Some Aspects of Hindu Medical Treatment. By Dorothea Chaplin (J. Charpentier) .

Studies in Indian History. By Surendranath Sen (J. Charpentier) : :

Studies in the Lankavatara-Sutra. By I. T. Suzuki (J. Charpentier) .

Catalogue of Photographs of Sanskrit MSS. By T. R. Gambier-Parry (J. Charpentier) .

Taittiriya-Prătik̄khya. Edited by Venkatarama Siharma Vidyabhushana

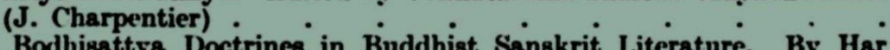

The Bodhisattva Doctrines in Buddhist Sanskrit I.iterature. By Har Daval (E. J. Thomas) .

Indian Logic in the Early Schools. By H. X. Randle (A. Berriedale Keith)

Pañcavimk̊a-Brähmaña. Translated by Ir. W. Caland (A. Berriedale Keith) .

Der gesetzmässige Lebenslauf der Völker Indiens. By Hartmut Piper (L. D. Barnett) . . . . .

Tocharische Grammatik. By E. Sieg and W. Siegling (N. Mironov) :
An Account of Tibet : The Travels of Ippolito Inewideri of Pistoia, s. J. (H. Lee Shuttleworth) .

The Religion of Tibet. By Sir Charles Bell (H. Lee Shuttleworth) : :

Trails to Inmost Asia. By George N. Roerich (H. Lee Shuttleworth) :

Europe and China. By G. F. Hudson (H. Dodwell) (H. Dodwell)

Indian Ialam. ${ }^{\circ} \cdot{ }^{\circ} \cdot{ }^{\circ}$.

Indian Islam. By Murray T. Titus (H. Dodwell) . . . . . . 1080

Travels of John Sanderson in the Levant. Hakluyt Society (H. Dodwell) 1081

Relations of Golconda in the Farly Seventeenth Century. Hakluyt Society (H. Dodwell)

Travels in India, Ceylon, and Borneo. By (aptain Basil Hall (H. Do.lwell)

Assam. Department of Historical and Antiquarian Studies. Bulletin No. 1 (Wolseley Haig)

Index to the Tso chuan. By E. D. H. Fraser (W. Perceval Yetts) : :

Chinesische Pagoden. By Ernst Boerschmann (R. F. Johnston)

Ausgewählte koptische Zaubertexte. By P. Angelieus M. Kropp (s. Gaselee)

Koptische Dialektgrammatik. By Walter Till (S. Gaselee) : ${ }^{\cdot} \cdot{ }^{*}$

Report on the Unification of the Shona Dialects. By Clement M. Doke (H. Jensen).

1028

1030

1033

1034

1034

1035

1037

1037

1038

1041

1048

1054

1055

1066

1072

1074

1079

1080

1082

1083

1085

1086

1087

1091

1093

1095

1097

\section{NOTES ANI OUERIES-}

Shams ud-Din Iltutmish-References to alchemy in Buddhist Seriptures-

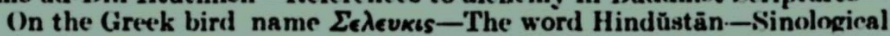
Studies 